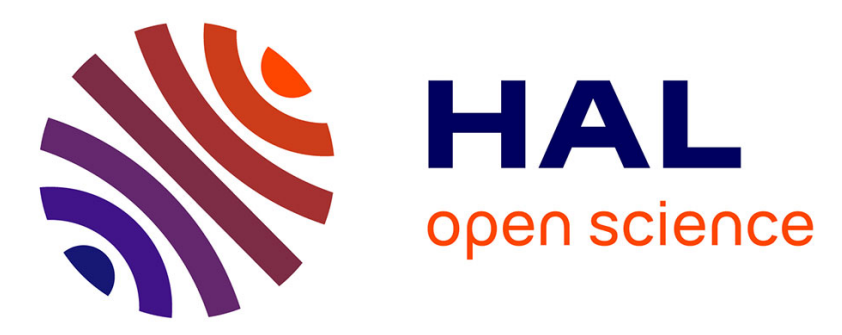

\title{
Stable epidemic control in crops based on evolutionary principles: Adjusting the metapopulation concept to agro-ecosystems
}

\author{
Lydia Bousset, Anne-Marie Chèvre
}

\section{To cite this version:}

Lydia Bousset, Anne-Marie Chèvre. Stable epidemic control in crops based on evolutionary principles: Adjusting the metapopulation concept to agro-ecosystems. Agriculture, Ecosystems and Environment, 2013, 165, pp.118 - 129. 10.1016/j.agee.2012.12.005 . hal-01208640

\section{HAL Id: hal-01208640 \\ https://hal.science/hal-01208640}

Submitted on 29 May 2020

HAL is a multi-disciplinary open access archive for the deposit and dissemination of scientific research documents, whether they are published or not. The documents may come from teaching and research institutions in France or abroad, or from public or private research centers.
L'archive ouverte pluridisciplinaire $\mathbf{H A L}$, est destinée au dépôt et à la diffusion de documents scientifiques de niveau recherche, publiés ou non, émanant des établissements d'enseignement et de recherche français ou étrangers, des laboratoires publics ou privés. 
Stable epidemic control in crops based on evolutionary principles: Adjusting the metapopulation concept to agro-ecosystems

\author{
Bousset L, Chèvre AM
}

INRA, UMR1349 IGEPP, F-35653 Le Rheu, France

\begin{abstract}
In agro-ecosystems, epidemics reduce crop yield. Disease development depends on interactions in time and space between host plants, pathogens, the environment and humans. There is an urgent need to reconsider disease control tactics by linking ecological and evolutionary concepts at the landscape scale, as achieved for natural ecosystems. The aim of our work is to adjust the geographic mosaic of coevolution theory between hosts and pathogens to agro-ecosystems. In agro-ecosystems, adaptation dynamics at the landscape scale depend jointly on annual epidemics, the flow between demes, and human actions, which exacerbate homogeneities in time and space. We describe a framework to take into account these direct and indirect human actions on host agro-metapopulations, which influence the size and composition of pathogen agrometapopulation demes. By linking disciplinary concepts it becomes possible to optimize the stabilization of disease control efficacy by designing management strategies to selectively apply evolutionary costs. At present, the pathogen agro-metapopulation adapts to its host and the other way around does not occur. However, these evolutionary costs can be used to maintain the pathogen agro-metapopulation locally nonadapted to the host agro-metapopulation. The use of this framework will allow crop protection approaches to be redesigned by modifying the host agro-metapopulation dynamics depending on the observed state of the pathogen agro-metapopulation.
\end{abstract}

Keywords: Epidemiology, Population genetics, Adaptation, Landscape scale, Human actions

\title{
Highlights
}

- The geographic mosaic of coevolution theory is adjusted to agro-ecosystems.

- Evolutionary costs allow taking into account both natural and anthropogenic processes.

- Epidemic control remains stable when local pathogen populations are maintained in a non-adapted state.

\section{Introduction}

In agro-ecosystems, human activity determines plant population dynamics and therefore has an impact on the development of disease epidemics. An ecosystem is defined as "a dynamic complex of plant, animal, and microorganism communities and their non-living environment interacting as a functional unit" (Millenium Ecosystem Assessment, 2005). Thus in the broadest sense an "agro-ecosystem" includes all managed and unmanaged environments, domesticated and wild communities as well as human communities (Loucks, 1977). In natural ecosystems, plant lifecycles determine their population dynamics in space and time (Gilbert, 2002). In turn, pathogen lifecycles evolve to exploit resources from host plants, which are related to the environment (Agrios, 2005). In contrast, in agro-ecosystems, plant population dynamics are also controlled by anthropogenic choices, because plant populations are organized into crops and managed toward production goals. In these crops, epidemic development depends on the interaction in time and space between host plants, pathogens, the environment and humans (Agrios, 2005). Major changes associated with agricultural intensification (Stoate et al., 2009) and pesticide availability made it possible to control biotic competition by weeds, pests and pathogens, and thus grow monocultures on large acreages. This had the unintentional effect of increasing the vulnerability of crops to diseases (Stukenbrock and McDonald, 2008). In this paper, we mainly focus on adaptation of a fungal pathogen to plant resistance. However, the theories discussed could be extended to other pathogens such as bacteria, viruses or insects, and to other control tactics such as fungicide use or cropping practices. Major changes associated with agricultural intensification also increased the dependence of production systems on pesticides, the usage of which we now wish to reduce.

As epidemics reduce crop yield, strategies combining several tactics are deployed to control them. Crop protection management strategies have the dual aim of achieving efficient and stable epidemic control. 
Their efficiency - i.e. capacity to produce an effect at one point of time and space - depends on pathogen biology and population size (Bousset and Chèvre, 2012). Their stability - i.e. the persistence of their efficacy in time and space - depends on adaptation dynamics in pathogen populations (Brun et al., 2010). In recent decades, concerted efforts have been dedicated to increasing efficiency; however maximizing efficiency failed to provide stability (Stukenbrock and McDonald, 2008). For example, the deployment of a limited number of resistant host varieties leads to an increase of compatible individuals in pathogen populations (Brown and Hovmøller, 2002). This in turn causes a loss of efficiency and "boom and bust" cycles over time (Browning and Frey, 1969). The underlying cause for this variation in efficiency is a change in the average level of adaptation of the pathogen population to the control tactic (Brun et al., 2010, Rouxel et al., 2001). The pathogen continuously adapts to the mosaic of host fields occurring at the landscape scale. Nevertheless, today the deployment (characteristics and localization) of each crop at the landscape scale is not chosen by taking into account the average level of compatibility of the pathogens present. Thus, there is room for improvement, to at least adjust the host in real time, or even to strategically anticipate changes in the pathogen population. Despite the need to consider evolutionary principles in crop disease management strategies, links between agronomic disciplines and evolutionary studies (Chevassus-au-Louis, 2006) are still lacking

To challenge current disease control measures (Pretty, 2008, Stoate et al., 2009) further links between various scientific disciplines are required. Blending plant genetics with epidemiology produced durable disease resistance selection (Johnson, 1984). Further blending with population genetics produced the pathogen evolutionary potential concept (McDonald and Linde, 2002, Stukenbrock and McDonald, 2008). Blending epidemiology and agronomy produced integrated crop protection against pests and diseases (Krupinsky et al., 2002). Yet, these links were developed without explicitly characterizing the efficiency and stability of the strategies. Recently, however, regarding efficiency, by decomposing population dynamics to take into account agro-ecosystem specificities control tactics could be connected to epidemiology (Bousset and Chèvre, 2012). To develop a stable management strategy to control epidemics in agro-ecosystems, a framework using evolutionary principles to define adaptation dynamics which also takes into account the specificities of agroecosystems would be extremely useful. Such a theory would connect disease control tactics at the different scales of the interaction between plants and pathogens.

In studies of natural ecosystems, the geographic mosaic of coevolution theory allows the adaptation dynamics, which connect scales spanning from molecules to ecosystems, to be considered (Thompson, 2005). At the individual scale, the changes to pathogenicity due to mutation or recombination on co-infected hosts, generates phenotype variability (Barrett et al., 2009, Rouxel et al., 2011). At the population scale, the average level of compatibility between the pathogen and host population is modified depending on host diversity. This diversity differentially affects a pathogen's ability for growth, multiplication or survival (Antonovics et al., 2011, Thrall et al., 2003, Laine et al., 2011). At the metapopulation scale (Hanski, 1999), the results of local interactions in time and space between host and pathogen demes determine offspring production (Laine et al., 2011). The local nature of these interactions, their differentiation and interconnection by migration produces the geographic mosaic of coevolution (Thompson, 2005). The speed of reciprocal changes in adaptation status is not uniform across space and time, leading to contrasting coevolutionary hotspots and coldspots (Thompson, 2005, Burdon and Thrall, 2009, Smith et al., 2011). The integration of these concepts, unified within a single theory, has increased our understanding of the interrelations between ecological and evolutionary processes in natural ecosystems (Thompson, 2005, Burdon and Thrall, 2009, Alexander, 2010, Laine et al., 2011), but not yet in agro-ecosystems.

Knowledge acquisition in the sciences of agricultural and natural ecosystems remains disconnected, potentially slowing down dissemination (REX Consortium, 2007). Despite the existence of pioneering work in metapopulations (Damgaard and Østergård, 1999), the adaptation of pathogens to host genetic discontinuity is still being modeled within the conceptual framework of population, without considering the impacts of fragmentation on the dynamics. In this context, fitness cost is introduced into mathematical models (Leach et al., 2001) to allow for the existence of an equilibrium state (Pietravalle et al., 2006, Sapoukhina et al., 2009). In some cases a fitness cost could be a leverage of action, especially in viruses (Janzac et al., 2009, Fabre et al., 2012) provided that the entire pathogen lifecycle is taken into consideration (Burdon and Thrall, 2008, Morris et al., 2009). However, human actions also clearly have an impact on pathogen adaptation in agroecosystems (Papaïx et al., 2011). While human activity alters pathogen/host coevolution (Sun and Yang, 
1999), few studies explicitly include this factor in the dynamics of adaptation. Thus, the development of a conceptual framework which links these elements while taking into account the specificities of agroecosystems is necessary. To represent not only the effectiveness but also the stability of strategies, we believe that the theory of coevolution in the context of metapopulations can be extended and adjusted to the specificities of plant diseases in agro-ecosystems (Thompson, 2005). The objective of this paper is to adjust these concepts to agro-ecosystems to help stabilize the control of epidemics in crops using evolutionary principles. In a first step, pathogen adaptation to both resistant and susceptible hosts is formalized taking into account temporal discontinuities. Adaptation dynamics in populations and metapopulations in natural ecosystems are then compared. Next, the key points needed to adjust the metapopulation concept to the context of agro-ecosystems and represent adaptation dynamics in agro-metapopulations are described. Then, how representing these dynamics within the framework can be used to optimize the stability of epidemic control is explored. Finally, the necessary interdisciplinary collaborations and key points for research are discussed.

\section{Temporal discontinuity and adaptation to two types of hosts}

Unlike natural ecosystems, agro-ecosystems are characterized by the presence of humans - hereafter referred to as "actors" - whose actions and choices interfere with the development of crops and epidemics. In agroecosystems, agricultural practices exacerbate the homogeneities and heterogeneities in the host and pathogen population dynamics (Bousset and Chèvre, 2012) inducing temporal, spatial and genetic discontinuities. One growing season, hereafter referred to as "season", is defined as the period during which there is no discontinuity in either the population of host plants or in the climate or cropping system. Thus in one season there can be a numerical increase in the pathogen population without any new influx of inoculum. However, alternating seasons cause temporal discontinuity in the environment.

When two host types are present, a second level of discontinuity in the system, caused by genetic differences in the host, is then superimposed on this temporal discontinuity. Both levels affect the dynamics of pathogen adaptation to resistance, and the subsequent magnitude of epidemics. We will first describe this dynamic for qualitative resistance, and then for quantitative resistance. Qualitative resistance establishes a clear qualitative distinction between "susceptible" and "resistant" hosts (Fig. 1). When qualitative resistance is efficient, the proportion of compatible pathogen individuals arriving in the field is low or null, which initially generates a small population on the resistant varieties. Thus, in the first season, epidemics are limited, as are symptoms and damage to the resistant variety. Virulent individuals, however, appear by mutation in populations present on susceptible plants. Thus, deploying susceptible and resistant varieties in the agroecosystem provides an automatic selective advantage to virulent individuals, which are compatible on all hosts while the avirulent isolates remain confined to susceptible varieties. Note that if virulence has a fitness cost on proliferation or survival, it will be expressed in competition on the susceptible variety only, because on the resistant variety there is no coexistence with avirulent individuals. If the resistant variety produces offspring in the following season, the frequency of virulent individuals will then increase in the regional population. Consequently, this change in composition of the pathogen population will result in a loss of host resistance efficiency. While the resistance remains fully effective against avirulent individuals, it is ineffective against virulent individuals.

Quantitative resistance affects the levels of compatibility more gradually than completely preventing infection of quantitatively resistant hosts. When quantitative resistance is efficient, all individuals in the pathogen population are compatible, but their lifecycle is negatively affected. Quantitative resistance against fungi generally acts by reducing the infection efficiency of spores, lengthening the latency period, and/or reducing the sporulation rate of lesions compared to the interaction on a susceptible host. When quantitative resistance is efficient, this results in a decrease in population size and slows down epidemic development. A loss of efficiency is called erosion due to the progressive nature of the phenomenon (Antonovics et al., 2011). If it exists in the population, more aggressive individuals, whose reproductive success is greater than average due to less effects on their growth and lifecycle, will increase in frequency over the generations. However, this increase in the average level of aggressiveness will be slower than for qualitative resistance. This occurs because of the polygenic control of aggressiveness, which leads to segregation of compatibility levels in offspring, and because less aggressive individuals are not immediately eliminated from the population. 
Fig. 1. Schematic representation of the pluriannual dynamics of an epidemic depending on the suitability of the climate and the annual dynamics of resistant (qualitative resistance) and susceptible host types. Environmental discontinuity (seasonal climates and annual host growth dynamics) is characterized by a temporal alternation of "seasons" and "discontinuities", which leads to alternating epidemic and survival phases. They are schematized by the succession, on each host type, of annual epidemics, inoculum production and inoculum transmission phases. Genetic discontinuity in the environment is illustrated for the discrete case of qualitative resistance, by the clear-cut distinction between "susceptible" and "resistant" hosts (compatibility table, different symbols and colors). The diversity of individuals within the pathogen population is represented by different symbols corresponding to compatibility (circles or stars) and to diversity within these categories (shadings). In the compatibility table, " $C$ " stands for compatible and " $i$ " for an incompatible interaction. The individuals represented by circles are not compatible on resistant hosts. Compatible individuals on resistant plants (stars) are generated by mutation on infected hosts, or by recombination on co-infected hosts. The disease reduction efficiency on susceptible and resistant hosts on which "all" and only "stars" individuals are compatible, respectively, depends on the flow between host types (arrows).
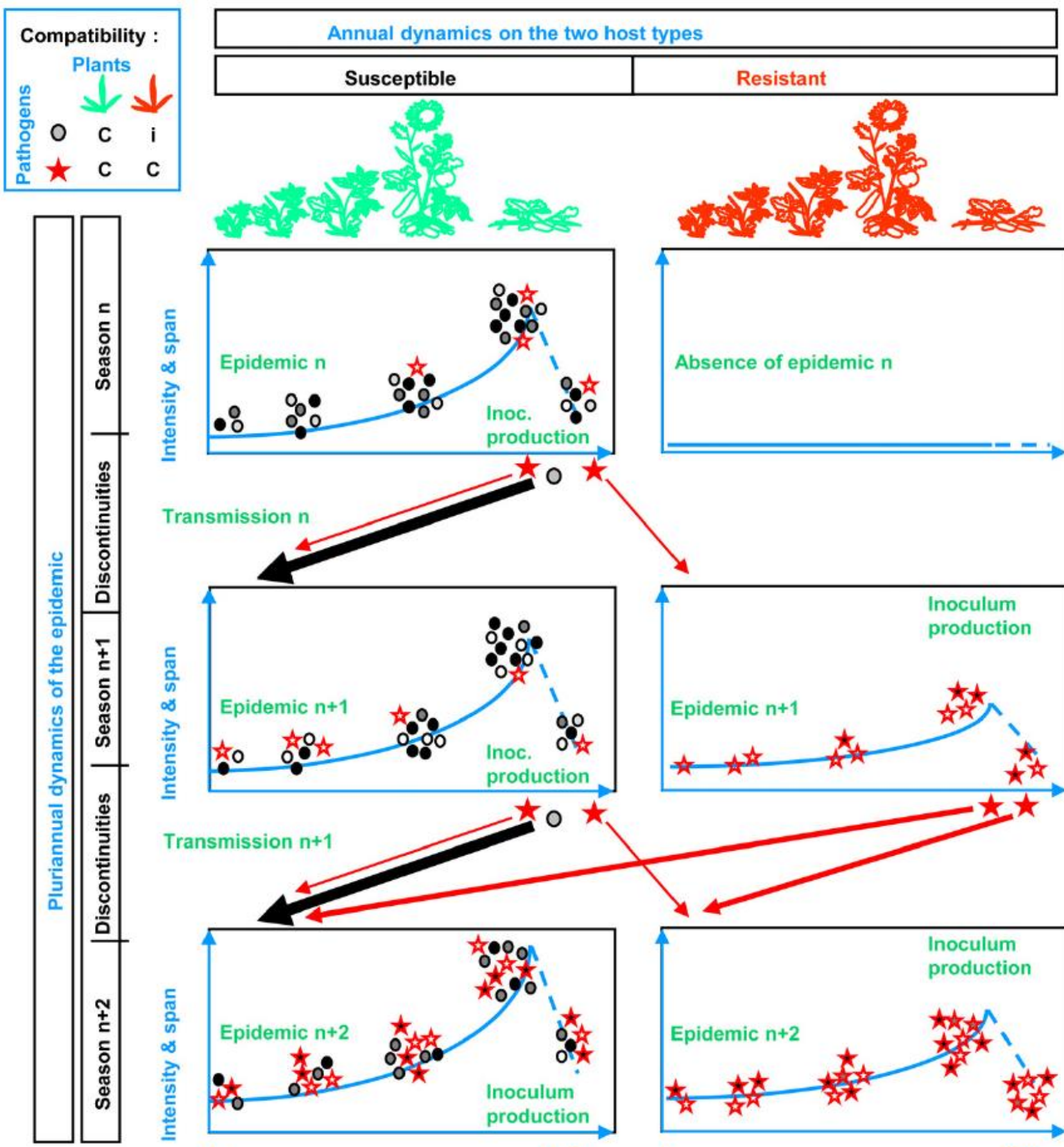

0

Time
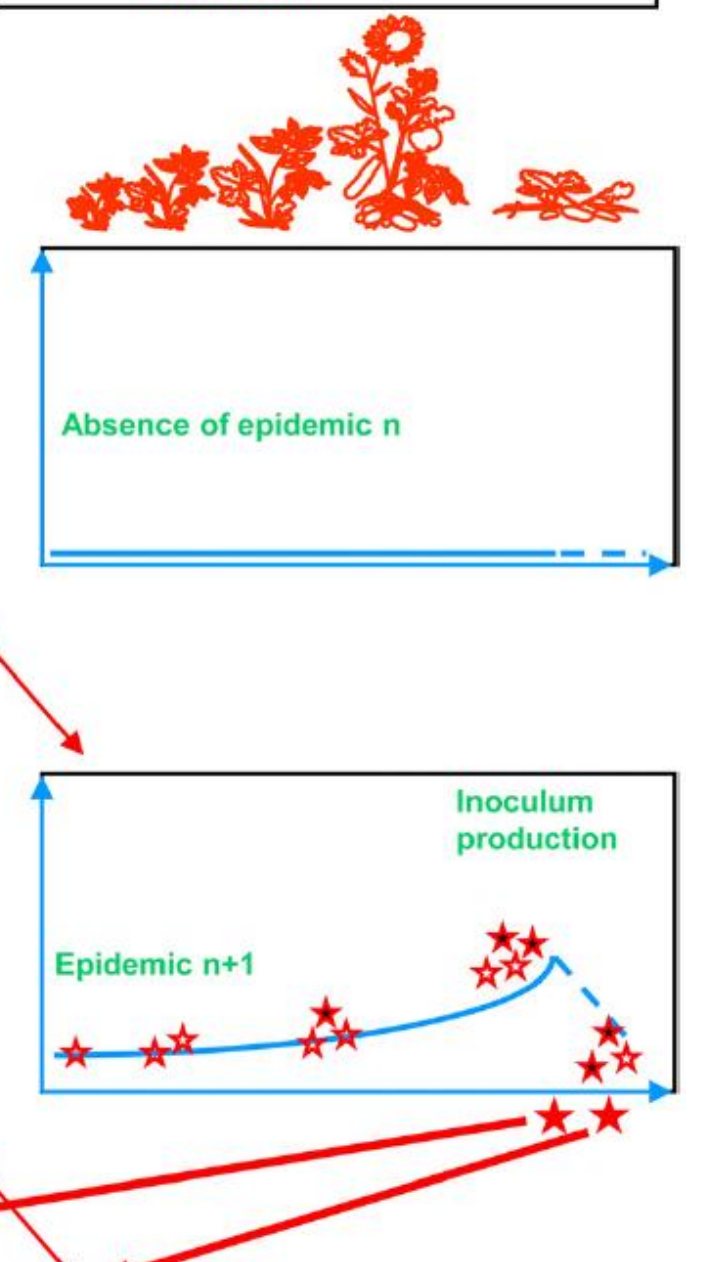
In both qualitative and quantitative resistance, at the scale of successive seasons in a set of fields, the increase in the intensity and spatial span of the disease is determined by the dynamics on each type of host during the season (local interactions) but also by the transmission process between seasons and between types of hosts (flow). Two conceptual alternatives are possible. The first alternative is that transmission is never a limiting factor. Each pathogen individual is spread across all hosts and each host plant is exposed to all pathogens. Hence, during the interaction the encounter between types is proportional to their respective frequencies. The second alternative is that due to heterogeneity in the presence of the host, transmission may be a limiting factor. This is because if dispersal is not sufficient, fragmentation of the host location can bias encounters. To take transmission into account, it is then necessary to represent the interaction between host plant metapopulations and pathogen metapopulations developing on these plants, while clearly defining the spatial and temporal discontinuity in the environment. In the following section, both alternative scenarios are developed further.

\section{Adaptation dynamics in populations and metapopulations in a natural ecosystem}

Adaptation dynamics result from the recurring interactions in successive generations, between host and pathogen individuals. The way the set of individuals in each partnership, in populations or metapopulations is represented, allows this dynamic to be described or not. In both cases, assumptions are as follows: the host population is diversified (including several host types); the pathogen population is diversified (including several pathogen types); the level of compatibility of one pathogen individual on one host individual is determined by the types to which they respectively belong. The two scenarios will now be described further, for the simplest case with offspring engaging in interactions in the immediately following generation. The approach remains valid for more complex cases including temporal carry-over of offspring (e.g. when resting spores or dormant seeds are produced) allowing for interactions between individuals produced in nonimmediately consecutive generations, but we will not examine these here.

To represent interactions between populations, the set of host individuals is a homogeneous whole, treated as a continuous space at the landscape scale (Fig. 2A). A pathogen population is distributed on the host population. The first step is selection and depends on reciprocal compatibility. At the individual level, if the interaction is not compatible, the pathogen individual dies (the case of resting spores is not considered here). If the interaction is partially compatible (quantitative resistance), pathogen growth is reduced, which has an impact on its capacity to complete its lifecycle. If the interaction is compatible, the pathogen lifecycle continues and has an impact on that of the plant. At the population level, the respective multiplication rates of hosts and pathogens can be calculated, and depends on both the respective proportions of each type within the population as well as the competition intensity. The second step is reproduction and carry-over of offspring. Even though generation times may be different, offspring production for the next generation of both the plant and pathogen depends on the interaction (Gilbert, 2002). This means that increasing compatibility in the interaction leads to a greater reduction in seed and an increase in the production of pathogen inoculum. From one generation to the next, survival is necessarily local. If one of the types becomes extinct, it can only be produced again by mutation. The adaptation process takes place over several seasons, during which each individual pathogen is spread across all existing host types and each host plant is exposed to all pathogen types. This induces a rapid increase in the frequency of compatible individuals (Fig. 2A).

To represent interactions between metapopulations (Gilpin and Hanski, 1991, Hanski, 1999), all sets of individuals are fragmented into subsets called demes. Because of the finite size of a deme, each does not necessarily contain all the existing types (Fig. 2B). The adaptation process takes place over several seasons, during which the average compatibility of the host and pathogen metapopulations results from local interactions - between one local pathogen deme and one local host deme - and from the migration flow between demes. This process is called coevolution (Thompson, 2005, Burdon and Thrall, 2009). Plant seed and pathogen inoculum production for the next generation depends on local interactions (Fig. 2B). However, the survival of types is not necessarily local because there may be local extinction and recolonization events. For both the host and pathogen, the transmission between demes depends on their connectivity, given their survival and dissemination abilities. During the successive seasons, for each deme there is a more or less strong genetic continuity and geographical stability modulated by extinction and recolonization (Fig. 2B). 
Depending on the composition of demes and migration flows, more plants may survive and the increase in frequency of compatible individuals may be delayed (Fig. 2B).

Fig. 2. Schematic representation of the pluriannual adaptation dynamics between hosts and pathogens (A) as an interaction between two populations, $(B)$ as an interaction between two metapopulations. Different symbols, and colors or shadings represent diversity of the plant and pathogen individuals. From the pools (individuals detailed in the left column, cumulated sizes in the right column) of seeds and spores surviving between discontinuities, the interaction results in compatibility selection (table; " $C$ " stands for compatible and " $i$ " for incompatible interaction) due to the death of incompatible individuals (crossed in red). The multiplication rate of each partner is affected by the interaction, which determines offspring production and transmission to the following season (the plants produce 2, 1 or 0 seed if uninfected, infected and multiply infected, respectively; the pathogens produce 3 spores in a single infection, no spores in multiple-infections). Changes in the cumulated sizes of the pathogen and plant population (size of the pies in the right column) depend on the number of compatible interactions and on these multiplication rates. This results in contrasting population dynamics between $(A)$ and (B). Between populations, the interaction is global, inducing a rapid increase in the frequency of compatible individuals (visible on cumulated sizes, right column). Between metapopulations, the fragmentation of the pools subject to the interaction allows for the maintenance of more plants, and slows down adaptation dynamics. Jointly, flow between demes and extinction/recolonization events participate to modify the dynamics, which can be observed by comparing the outcome of the same interaction (A) as an isolated population (doubled for consistency of metapopulation size) and (B) as one deme subject to flow. (For interpretation of the references to color in this figure legend, the reader is referred to the web version of the article.)

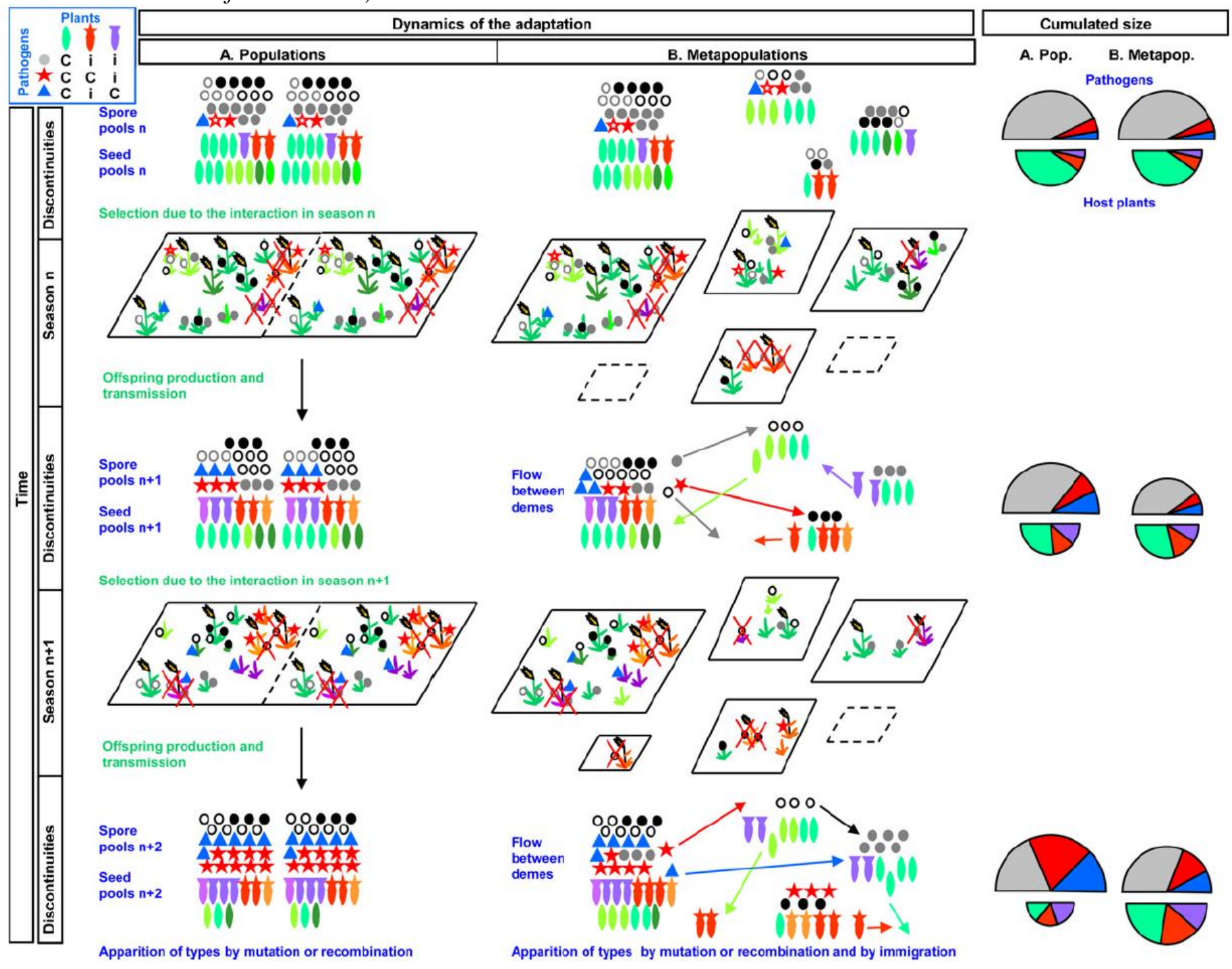


The evolutionary equilibrium states, in which the effectiveness of resistance remains stable, differs between these two different scenarios. In a pathogen population, a balance may be reached if (i) there is no appearance of virulent individuals (Schwarzbach, 1998), (ii) a fitness cost on susceptible hosts exactly offsets the advantage gained by virulent individuals on resistant hosts (Leach et al., 2001), (iii) sufficient new interaction specificities are generated, which therefore continuously modify the reciprocal compatibility between pathogens and hosts and create a cycle (Leonard, 1993). In a metapopulation, there is an additional global equilibrium state, which depends on both local interactions and flows between demes (Damgaard and Østergård, 1999, Thompson, 2005). In agro-ecosystems, the search for stable states of efficient resistance (or resistance durability) was undertaken in populations, but seldom in metapopulations (Damgaard and Østergård, 1999), due to the lack of an appropriate framework.

\section{The metapopulation concept needs to be adjusted to the context of agro-ecosystems}

Given the combination of spatial, temporal and genetic continuities and discontinuities described in an agroecosystem, (Bousset and Chèvre, 2012) a fragmented context is actually often more appropriate than a continuous model for both the host and pathogen. However, it is necessary to adjust the metapopulation concept because the number of interacting partners is different. Within the geographic mosaic of coevolution between one pathogen species and one host species, the outcome of the bipartite interaction is locally modified when other species interfere (Thompson, 2005). In natural ecosystems, the local interaction can be tripartite, for example in the presence of a hyperparasitic species, an alternate host species for the pathogen or some competing species (Thompson, 2005). However, across the metapopulation, additional partners present in each of the demes vary in time and space: it is not always the same species that interferes. In contrast, in the agro-ecosystem, the plant-pathogen interaction becomes tripartite because there is always an interaction with the same additional partner, man. We propose the term "agro-metapopulation" because due to human actions, neither the interaction nor the demes or the migration have the same structure as in natural ecosystems. The description of these three elements will now be explored in detail.

The interaction between pathogen and host plant demes is affected by human actions (Fig. 3). The metapopulation model assumes that exposure to local selection pressures influences the evolution of each deme, which is biased for two reasons within the agro-ecosystem context. On one hand, when the migration intensity increases relative to the local survival rate, the impact of local interactions decreases. This means that locally interacting demes are less affected by one another, and more affected by the demes from which the migrant individuals originated, and on which different selection pressures can act (Gandon et al., 1996). On the other hand, human selection may act against local natural selection. Except for special cases where there is no tactical control possible during the season, the result of plant-pathogen interactions in the previous season is not a key factor in the choice of host or for the selection of cropping practices. The respective contribution of natural (the result of local interactions) and anthropogenic (choice of host, cropping practices which affect the local population structure and size) effects on the constitution of demes for the next season may vary in intensity over time and space, and be more or less significant depending on the agro-ecosystem considered.

In the host plant agro-metapopulation, actors alter plant populations to increase the efficiency of resource extraction from the ecosystem. The first consequence - due to the human selection of the plant material to be cropped - is the reduction of genetic diversity within species and within demes (Fig. 3B). Accordingly, within cropped species, the intensification of agricultural practices has failed to preserve all the strategies of plant adaptation or disease avoidance selected in natural ecosystems. The second consequence due to cropping practices and rotations - is the discontinuity of deme location, superimposed on the discontinuity of their genetic composition when different varieties are cropped (Fig. 3B). While in natural ecosystems, the changes can be gradual and similar between areas (Fig. 3A); in the agro-ecosystem changes are abrupt and variable between zones (Fig. 3B). In the most drastic case, when the species cropped in one field is changed in the following year, this means that none of the offspring will grow at that location. In contrast, monoculture of the same variety could even increase the presence of the host, compared to harvested offspring. Incomplete weeding of volunteers will produce an intermediate situation. Thus in the long term, human technological and regulatory choices have channeled the evolution of host agro-metapopulations (Bonneuil and Thomas, 2009). 
Fig. 3. Schematic representation at the scale of one deme, located either $(A)$ in a natural ecosystem, or $(B)$ in an agro-ecosystem. Cumulated population sizes (size of the pie charts, inner columns) of seed pools (below horizontal) and spore pools (above horizontal) correspond to the detail of individuals (outer columns) present in left and right zones, respectively. Changes in population size from one season to the next depend on the number of compatible interactions (table; " $C$ " stands for compatible and " $i$ " for incompatible interaction) and on multiplication rates (described hereafter). For the host plant, the localization, number, phenological stage and individual genotypes depend on human choices in the agro-ecosystem; and on reproductive success of their parents in the natural ecosystem. The multiplication rate is affected by the interaction, each plant produces 2, 1 or 0 seed if uninfected, infected and multiply infected, respectively. For the pathogen, the interaction results in compatibility selection due to (table) the death of incompatible individuals (crossed). Their multiplication rate is affected by the interaction and by the local density of compatible hosts. In the natural ecosystem, each pathogen individual produces 3 spores in a single infection, no spores in a multipleinfection; in the agro-ecosystem, each pathogen individual produces 4 spores in a single infection, 1 in multiple-infections. This leads to contrasting population dynamics between $(A)$ and $(B)$. In the natural ecosystem, the stability of host genotype localization and diversity induces changes in the pathogen population that are gradual and similar across zones. In the agro-ecosystem, unstable localisations and host genotypes induces abrupt changes in the pathogen population of variable magnitude across zones. This affects the seed yield of each zone.

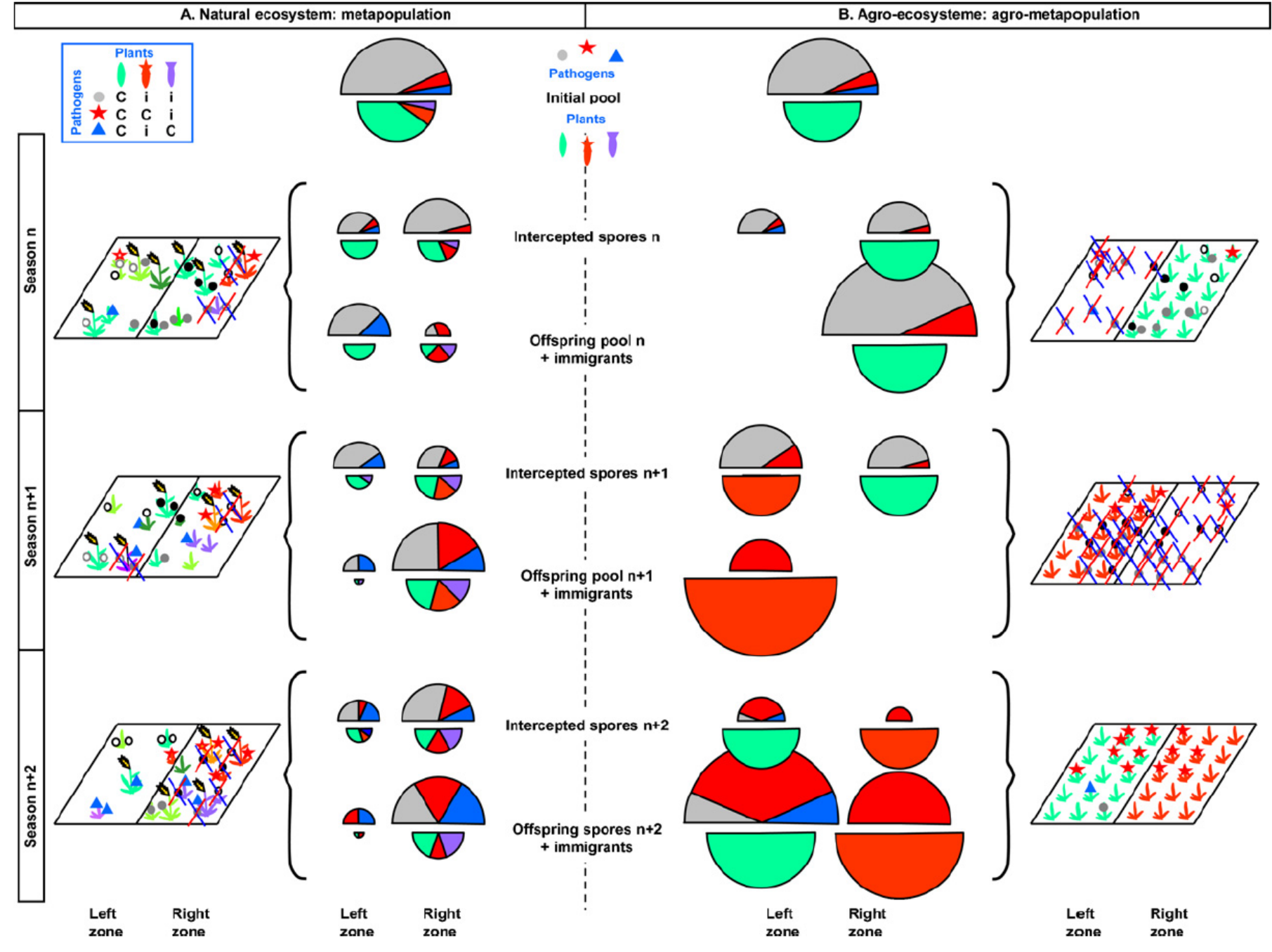

In the pathogen agro-metapopulation, actors directly (control tactics) and indirectly (alteration of the host type) modify those pathogen populations which were perceived as a factor limiting plant productivity. Disease control tactics affect deme persistence (Fig. 3) and the structure of migration flows, in both the short 
and long term. In the short term, changes in a natural ecosystem are gradual (Fig. 3A), but pathogen population dynamics in an agro-ecosystem include abrupt and variable changes between zones (Fig. 3B). In the most drastic case, the pathogen population could be completely eradicated in one field, using fungicides (assuming complete success). Whereas, cropping of a very susceptible variety could lead to tremendous amplification of the pathogen population. Partial fungicide efficacy, moderately resistant varieties and association with appropriate prophylactic measures will produce an intermediate situation. In the long term, the characteristics of agro-ecosystems channel pathogen evolution to generate lifecycles which include, rapid and prolific multiplication, when the main host is present and homogeneous or, when the primary host is absent, infectious units best suited to survival between seasons and dispersal between host patches, or to the infection of alternate hosts (Stukenbrock and McDonald, 2008) or several species.

Finally, the metapopulation model is more of a conceptual abstraction rather than an accurate representation of reality. However, even more than in natural ecosystems, the issue arises of the scale at which it can be applied to in agro-ecosystems. In such a landscape, the density of suitable habitats is continuous in space but unstable over time. The main question is the how to represent that fragmentation. In natural ecosystems, habitat diversity and discontinuity lead to a host population which is fragmented into entities with a certain geographic permanence in time. However, man alters agricultural environments to make them suitable to certain crops over large areas. In a given season, in these spaces, there is fragmentation into fields or patches. Yet, this fragmentation is unstable over time: a same host species is not always preserved in a given field it is more common for rotations to be used to ensure that each crop is located in different fields of the farm during successive seasons. To take this environmental discontinuity into account, an agro-ecosystem can be represented as a mosaic of spatial and temporal host and non-host patches, spread over an area, or landscape (Bousset and Chèvre, 2012). Each patch, hereafter referred to as a "field" corresponds to a cultivated field or, when appropriate, a non-cultivated population of a host species (Morris et al., 2009). However, this mosaic is not necessarily at the scale of the metapopulation. On one hand, the capacity of pathogens to disperse may exceed the distances between fields, joining several fields together in a common deme. On the other hand, the temporal instability of the host may make it necessary to expand the scales to obtain a level of stability between demes over time.

An understanding of the interaction between pathogen lifecycles, and the host crop dynamics which determine epidemics, is key to developing stable epidemic control strategies. Thus, the principles of adaptation in metapopulations must be adjusted to take into account human actions.

\section{Adaptation dynamics in agro-metapopulations}

Once it is recognized that agro-metapopulations have specific structures and that man acts within them, it is possible to include these features to formalize the interaction between metapopulations. The contrast between a natural ecosystem (intrinsic processes only) and an agro-ecosystem (anthropogenic processes superimposed on intrinsic processes) will be illustrated for one simplified situation (Fig. 4).

The result of a local interaction between a host deme and the corresponding pathogen deme depends on their reciprocal characteristics and human actions. These factors can be taken into account by representing, at each of the interaction sites, the bias induced by human choices for the host, and, the bias induced by cropping practices for the pathogen (Fig. 4). Local increases in the host or pathogen are not only due to improved local performance in the agro-ecosystem. The cultivation of a poor performing variety - in terms of seed yield or disease resistance - may increase if it is associated with technical (e.g. suitability to transport, marketing or processing) or cultural (e.g. taste) preferences (Zhu et al., 2000). Similarly, inoculum survival or transmission can be more effective for individuals who are poorly adapted locally but in a field that is not subject to disease control, than for better adapted individuals in a field subject to strict sanitary control (Daverdin et al., 2012). Therefore, to represent the interaction between agro-metapopulations, it is necessary to introduce an anthropogenic bias term, for both the host and the pathogen demes (Fig. 4), which completes the result of each local interaction (Fig. 3). 
Fig. 4. Schematic representation of the pluriannual dynamics of deme size and composition in an environment which is discontinuous in time and space, for a natural ecosystem ( $A$ and $B)$ and an agro-ecosystem $(C$ and $D)$. Changes in population size from one season to the next depend on intrinsic processes (migration, compatibility, and multiplication) and anthropogenic processes (seed auto-production or purchase from retailers, population eradication, flow amplification or interruption). Cumulated population sizes (pie charts, inner columns) of seed pools (below horizontal) and spore pools (above horizontal) correspond to the detail shown for individuals (outer columns) illustrated for one of the demes. The genetic discontinuity of the environment is illustrated by the distinction between "susceptible" and "resistant" hosts (compatibility table, different symbols and colors), the diversity of which is represented in detail for the populations of one of the demes (A and D). Offspring (seeds and spores) production intensity depends on the interaction. Effective migration is represented by arrows between demes. The contrast between structure and dynamics is due to human actions. These anthropogenic disseminations can be represented by their interventions which affect the composition of the host population (seed self-production or purchase from retailers), the migration between demes (promoted or interrupted) and the contribution of local inoculum pools to the following season (maintained or eradicated). The local absence of a population in one deme is represented by dashed lines. (For interpretation of the references to color in this figure legend, the reader is referred to the web version of the article.)

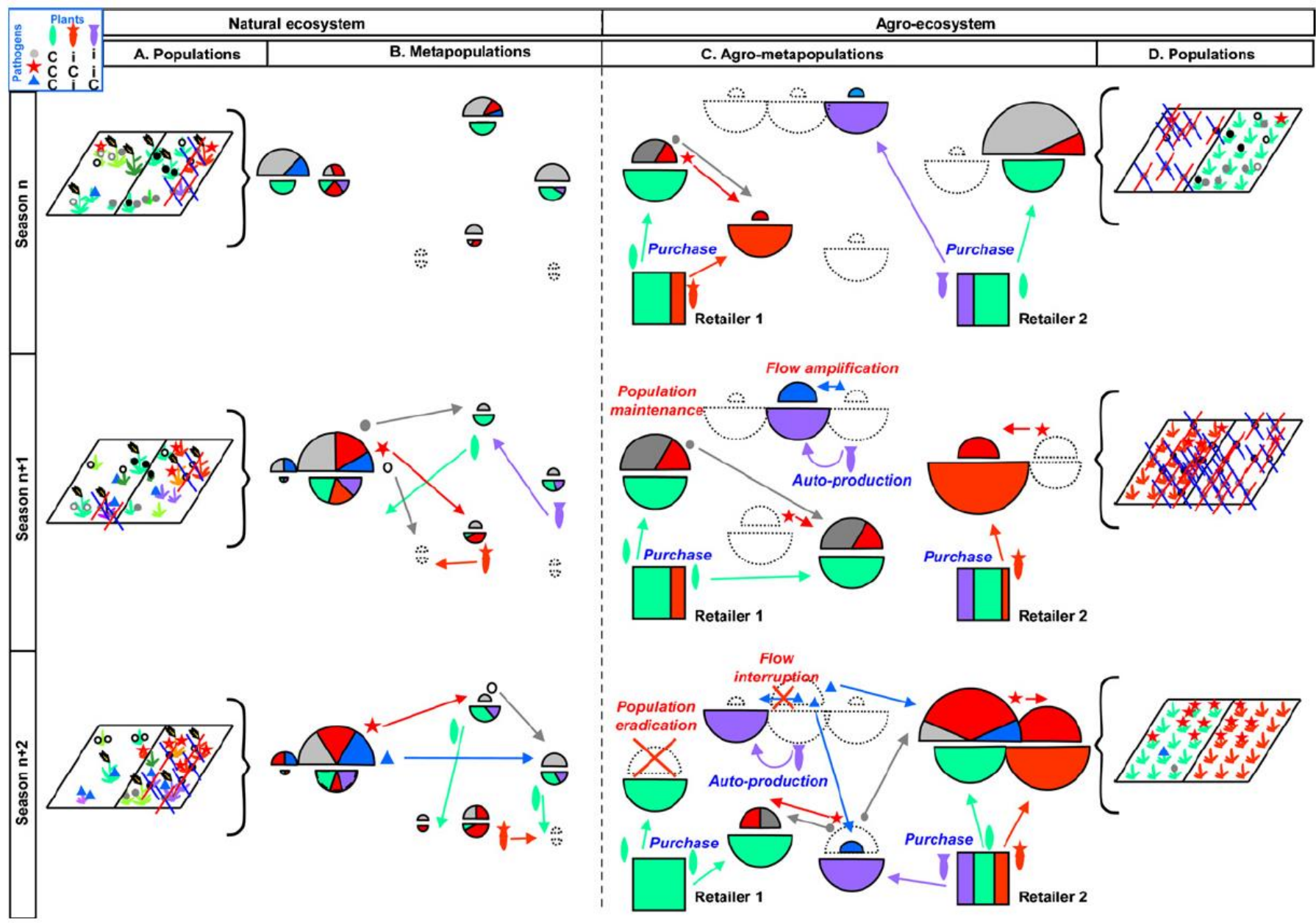

The structure and processes of the host plant agro-metapopulation must be specified for each agroecosystem and for each host plant species, depending on both intrinsic features and human choices. Intrinsic features include the biology of the plant, the soil, climate and biotic environment, which affect the structure (size of demes, locations) and persistence of demes (whether or not to replant the same crop for several seasons in the same plot; persistence or not of crop stubble, presence or absence of volunteers). Human choices include (i) the local structure of production chains affecting the regional density of a given species, (ii) the distribution of seed networks and the rules concerning the registration of varieties which has an impact on both the 
structure of migration flow of the host between demes, and the local persistence of demes (Bonneuil and Thomas, 2009). To represent the host plant agro-metapopulations, it is necessary to take into account both the areas which are biologically suitable for cultivation and the human choices for the location of demes. For migration flow, it is essentially the seed exchange network that will be described (Fig. 4). Indeed, unless farm seeds are self-produced, the seeds sown in a field are rarely the descendants of the seed produced in this given field in the previous season (Ambec et al., 2008, Bonneuil and Thomas, 2009). In the following, "seed" refers to the initial plant material, whether seeds, tubers, cuttings or seedlings. "Variety" refers to plant material selected and chosen by the farmer without prejudging either its homogeneity or genetic structure. On-farm seed production restricts migration to the scale of the farm. These seeds "migrate" from the fields of the same farm, after exposure to local natural selection pressures and the farmer chooses which varieties to sow among those grown in previous years (Bocci and Chable, 2008). When the farmers chooses to buy seeds of a particular variety from one or more local retailer or exchanges seeds with another farmer, varieties "migrate" from this/these source(s) to the farmer's fields (Brush and Perales, 2007, Delaunay et al., 2008, Jarvis et al., 2008) (Fig. 4C). At a larger scale, varieties "migrate" to the local retailer (and make up the assortment of varieties proposed to local farmers) from one or more production units belonging to one or more breeder, after the retailer makes a selection from the varietal assortment proposed by each breeder. In each production unit, the varieties are potentially exposed to natural selection in the local environment. However, for disease resistance, natural selection can only take place if there is variability within the variety (not in pure lines, clones and F1 hybrids) and if the diseases are not excluded by strict sanitary control in seed multiplication fields. Before multiplying seed, breeders (either professional seed companies or farmers engaged in participatory selection networks) control the processes to (i) select the genetic diversity introduced during selection schemes (by choosing progenitors from wild relatives, from other varieties, or potentially from another genus by genetic manipulation; Glaszmann et al., 2010); (ii) direct human selection by the choice of selection schemes (choice of parents for crosses in every generation); (iii) expose plants to natural selection (selection of test sites for evaluation of the material under natural conditions over a limited time, selection of pathogen populations when artificial inoculations are used). Therefore, to represent the host agro-metapopulation, it is necessary to represent not only the cultivated fields, but also the relevant actors in the seed exchange network. At least retailers (Fig. 4C) should be included because local demes of the host plant are established from their pools of seeds rather than from seed produced by that deme at the end of the previous generation as in natural ecosystems (Fig. 4B).

The structure and processes of the pathogen agro-metapopulation must also be specified for each agroecosystem and each pathogen species, depending on intrinsic and human choices. Intrinsic features include pathogen biology which affects deme persistence (survival modes) and migration (modes of dissemination); as well as the soil and climate which shape suitable environments. Human choices include cropping practices for the host species (e.g. those that make the environment less conducive to survival such as plowing or changing the soil $\mathrm{pH}$ ) and disease control practices (disinfection of exchanged equipment and seeds, prophylaxis, and destruction of inoculum). Deme persistence depends on human actions as well as biological capacity (Fig. 3, Fig. 4). In extreme cases, the next generation consists exclusively of migrants with no local persistence, either because of direct action to control the pathogen (e.g. successful disinfection practices; Sosnowski et al., 2009) or because of actions which modify the host (e.g. following harvest of the host of a strictly biotrophic pathogen with no capacity for local survival or after the ban of a crop at the national level; Brown and Hovmøller, 2002). The migration network also strongly depends on human actions as well as biological capacity (Fig. 4C). Human actions can not only prevent transmission by regulating sanitation practices (e.g. seed certification, Breukers et al., 2007; eradication of alternate hosts, Sosnowski et al., 2009) but can also increase it by anthropogenic dissemination (e.g. direct displacement of pathogens, Hulme, 2009; seedling trade, Prospero et al., 2009; or the structure of the seed distribution network, Delaunay et al., 2008). Therefore, to represent the pathogen agro-metapopulation, the anthropogenic-derived flow contributing to dissemination (Fig. 4C) is included in the framework to complement the natural flows connecting demes in natural ecosystems (Fig. 4B).

Once these features are taken into account, the geographic mosaic theory of coevolution applies. This amounts to explain what Thompson (2005) described as agricultural coevolution. 


\section{Optimizing the stability of epidemic control strategies using agro-metapopulation dynamics}

After fully characterizing agro-metapopulation dynamics, it becomes possible to formalize a relationship between adaptation to disease control tactics and principles for optimizing management strategies. By taking into account both natural and anthropogenic processes, the composition of the host agro-metapopulation can be adjusted to fit the observed status of the pathogen agro-metapopulation, or even to anticipate its evolution. In the agro-ecosystem, the efficiency of epidemic control can be deconstructed into specific aims, each corresponding to a component of the pluri-annual dynamics of epidemics (Bousset and Chèvre, 2012). Management can be split into management at the field scale, in which benefits are obtained in one field from action taken in this same field, and management at the landscape scale, in which benefits are obtained in one field from action in the landscape in which it is located. The efficiency of epidemic control is the reduction of damage in one year in a field compared to the same field in a landscape consisting solely of susceptible varieties without disease control. It is optimized based on a strategic combination of disease control tactics. Stable epidemic control is achieved when the efficiency is maintained over successive seasons. It can be optimized by maintaining the local non-adaptation pathogen agro-metapopulation to the host agrometapopulation. The process of adaptation of pathogen populations takes place over several seasons and several fields, therefore requiring integration - in the mathematical sense - over all fields of the landscape. When disease control is implemented across a landscape, among individuals present locally, those which are adapted to the control method have increased reproductive success (Fig. 1). If the contribution of each field to the pool of spores mobilized at the beginning of the next season is directly proportional to its area (Hovmøller et al., 1997), the benefit of individuals adapted to the control method is the ratio of the areas on which disease control is applied or not. Without managing the stability (e.g. the use of host genetic resistance), these adapted individuals will increase in frequency and invade the pathogen agro-metapopulation (Hovmøller et al., 1997; Fig. 1). The balance at the landscape scale - and therefore the stability of the efficiency of the control method - can be obtained if this selective advantage is offset by a cost. We propose to expand the concept of "evolutionary cost" to describe both the "intrinsic evolutionary cost" previously identified and the "anthropogenic evolutionary cost" not yet exploited. The latter recognizes that human actions affect the pathogen agro-metapopulation both directly and indirectly (Fig. 3, Fig. 4). We will start by describing these costs, before explaining how to use them as levers to choose the composition of the host agro-metapopulation.

The intrinsic evolutionary costs result from biological processes reducing the contribution of spores per unit area where the disease control tactic is applied, compared to where it is not. These costs express the penalty, in terms of reproductive success, caused to pathogens by their biological characteristics. This includes (i) reducing epidemic severity in plots where the disease control tactic is implemented, which is a possible hypothesis to explain the gain obtained by combining qualitative and quantitative resistance (Lô-Pelzer et al., 2009, Brun et al., 2010); (ii) reducing the reproductive success of individuals adapted to the disease control tactic during periods when disease control is not applied. This decreased success in competition is also called fitness cost (Vera Cruz et al., 2000). The fitness cost may be expressed during the growing season - by reducing the mobilization of inoculum or its amplification - and during the discontinuities - through reduced survival and transmission by vectors (Morris et al., 2009).

The anthropogenic evolutionary costs result from the interaction between human actions and the expression of pathogen life-history traits. These costs express the penalties, in terms of pathogen reproductive success, occurring when their inherent biological characteristics interact with anthropogenic choices. These include (i) the cost to diversity within the pathogen population resulting from a reduction in population size during the season and discontinuities (Pannell and Charlesworth, 2000); (ii) the cost to dispersion obtained by reducing landscape connectivity in space (Margosian et al., 2009); (iii) the cost to survival obtained by reducing landscape connectivity in time (Finckh and Wolfe, 2006), and (iv) the cost to the average level of compatibility, obtained by reducing the similarity of the varieties used in successive seasons (Finckh and Wolfe, 2006). Although each of these processes has previously been proposed as potential leverage for management, what is new is to translate them in terms of costs, which is made possible by the representation of the agro-metapopulation dynamics proposed in our framework.

In the agro-ecosystem, there is no coevolution between hosts and pathogens at the landscape scale. The pathogen agro-metapopulation continuously adapts to the host agro-metapopulation that it encounters. In contrast, the other way around is not true: changes in the host agro-metapopulation composition are not 
intentionally chosen depending on the pathogen agro-metapopulation present. Realizing how important the consequences of human actions are on the dynamics of reciprocal adaptation allows strategies to be developed in which the host could be in advance and not always lagging behind in this evolutionary race. The stability of epidemic control can also be broken down into specific aims, each corresponding to a component of the pluri-annual dynamics of the pathogen agro-metapopulation: deme size (number of individuals), level of adaptation to the local host deme, and level of connectivity with the surrounding demes. To optimize the stability of the efficiency of disease control, management strategies are designed to selectively apply evolutionary costs. Evolutionary costs are adjusted, in order to maintain a pathogen agro-metapopulation which is non-adapted to each of the corresponding host agro-metapopulation demes. Intrinsic evolutionary costs can be maximized by selecting varieties that impose the strongest fitness costs on the pathogen. This is possible when quantifiable predictors are identified (Leach et al., 2001, McDonald and Linde, 2002, Janzac et al., 2009) and led to selection for durable resistance (Johnson, 1984) or to resistance combinations (Brun et al., 2010) to increase the durability potential of varieties (Bousset et al., 2011). By conceptualizing anthropogenic evolutionary costs they can be maximized by acting on the agro-metapopulation dynamics, which allows them to be combined with natural evolutionary costs. Furthermore, evolutionary costs may be selectively increased in certain fields to prevent the pathogen agro-metapopulation adapting (Hovmøller et al., 1997). For example, transmission between fields in which the same control tactics were implemented in successive seasons can be specifically hampered, and the recurrence of selection pressures over time can be avoided by means of dynamic cropping systems (Hanson et al., 2007). This offers a conceptual base to combine control tactics in order to increase their potential for durability.

In this paper, we have outlined a simple situation, specifically describing the adaptation of a fungal pathogen to plant host qualitative resistance. This is not yet fully consistent with the real situation in agriculture. But where necessary this basic framework could be extended to include more complexity. In reality, multiple pathogens and pests occur simultaneously. Though specific features could be added, such as vection for viruses or active plant host selection for pests, the selection processes described for fungi hold true for other pathogens and pests. One important point is that developing the same framework to represent simultaneous infection with different pathogens and pests makes it possible to take into account their interaction, or to evaluate disease control tactics against several crop protection problems. In reality, several crops can also be host to the same pathogen. Thus the same framework could also be developed for several host crops to include interactions between them, such as partial carry over or amplification of inoculum on successive crops within the rotation. Although fields are represented in the figures, some of the patches could be natural or semi-natural habitats. This would allow the dynamics in each compartment of the agro-ecological interface to be specified simultaneously (Burdon and Thrall, 2008). Finally, in reality, epidemic development and transmission can be modulated by additional factors. Some are intrinsic, such as climate. Climate could be represented through its effect on epidemic dynamics (e.g. infectivity, amplification, survival, dispersal; Bousset and Chèvre, 2012) and differentiated depending on the demes, or on the generation. Other factors are anthropogenic such as fungicide application or cropping practices. The limits to model complexity are the ability to keep track of such a multi-dimensional object, not to mention the difficulty in obtaining the corresponding data.

Since human choices are key to the adaptation of pathogens to their host plants, the observed time over which epidemic control remain efficient and stable will always depend on the collective management of the agricultural ecosystem.

\section{Interdisciplinary collaborations and key points for research to optimize the stability of epidemic control strategies}

The agro-ecosystem is a discontinuous environment, with host crops exploited for production. This study proposes a formal framework to represent fluctuations in the size and composition of pathogen agrometapopulation demes and link human action to the physical (soil, climate, physical landscape, i.e. network of fields), biological (host agro-metapopulation, additional species) and social (production aims, human landscape, i.e. network of farms, network of actors, i.e. production sectors) environments. Our main contribution is to propose a novel approach which takes into account all these different biological characteristics and knowledge from diverse scientific disciplines. This offers a unique conceptual basis to look 
for local solutions to preserve the stability of the efficiency of disease control tactics. Processes are universal, but optimal solutions are locally specific. "Local" refers to the crop, biology of the pathogen, production situation and available tactics. In an agro-ecosystem at some point in time, a collection of multidimensional constraints - including what is known and what is not about each of the partners in the interaction and its environment - determines the optimal tradeoff between efficiency and stability. Possible improvements are not absolute, but would depend on their costs and margins for maneuver determined by the flexibility of the other links in the interaction. It is crucial to realize that action on one of the partners in the system will cause reactions in the links and other partners, with adaptation over time. These reactions can not be ignored given the temporal dimension of the problem, but understanding all the factors together is out of reach. To find a solution, simplification of the issue at the local level is required.

The first key point for research involves the differentiation of management objectives according to whether the pathogen is endemic or epidemic. In the case of previously absent pathogens, stability is sought by eradication, and criteria determining the persistence and invasion (Gilligan and van den Bosch, 2008) have been proposed for polyetic epidemics. The representation described in this paper allows this approach to be extended and closer links to be made between natural and anthropogenic processes, which are connected in the same epidemiological context. For example, we could use it to understand how to reduce flow between demes, which results jointly from cropping practices (size of the source and receptivity of the target crops), human dissemination between demes, and natural dispersal (Hulme, 2009, Prospero et al., 2009). In the case of locally established pathogens, stable control of cyclic epidemics can be pursued by acting on the local equilibrium. The goal is not eradication, but maintenance of local non-adaptation. This can be achieved by limiting flow in relation to population differentiation and compatibility in relation to the efficiency of control tactics (Fig. 4). For this, theoretical studies are needed to link the maintenance of local non-adaptation to human actions. The link between pathogen evolutionary ecology and the development of sets of cropping practices (Hossard et al., 2010, Lô-Pelzer et al., 2010) or varieties (Bousset et al., 2011) has to be developed further.

The second key point for research is the acquisition of empirical data on evolutionary costs. This will involve documenting (i) the processes involved in the dynamics of pathogen agro-metapopulations, e.g. inoculum production (Lô-Pelzer et al., 2009), fitness costs elsewhere than in the field during the growing season (Morris et al., 2009) and anthropogenic dissemination between fields (Prospero et al., 2009); (ii) the efficiency of control tactics depending on population size and adaptation levels (Brun et al., 2010, Lô-Pelzer et al., 2010, Daverdin et al., 2012); (iii) the structure of the host agro-metapopulation in relation to breeding (Bonneuil and Thomas, 2009), the choice of varieties (Brush and Perales, 2007), the seed exchange network (Jarvis et al., 2008, Thomas et al., 2011) and damage (Savary et al., 2006).

The third key point for research relates to the type of collective landscape management, whether it is centralized or decentralized depending on local objectives. On the one hand, this would involve multicriteria optimization (Sadok et al., 2009) in particular the search for a compromise between efficiency and stability. On the other hand, this would require strengthening the links between the development of cropping systems (Bergez et al., 2010, Doré et al., 2011) their allocation in the landscape (Leenhardt et al., 2010) and their consequences on pathogen adaptation (Lô-Pelzer et al., 2010). Finally, the notion of evolutionary cost allows the link to landscape ecology (Burel and Baudry, 2005), for example through the quantification of connectivity (Rozenfeld et al., 2008).

The prospects for interdisciplinary research are, for example, evolutionary cost optimization by a set of interrelated actors (Vanloqueren and Baret, 2008) and the link to economics (Goldman et al., 2007, Lansink, 2011) provided that the concept of ecosystem services (Costanza et al., 1997, Cheatham et al., 2009) is adjusted to processes that include evolution (Bousset, 2011).

\section{Acknowledgements}

The authors thank F. Fabre, C. Lannou, E. Lô-Pelzer, I. Sache and N. Sapoukhina for fruitful discussions. S. Bouhallab, L. Gebbie and B. Chevassus-au-Louis are thanked for helping to improve the manuscript. This work benefited from the financial support of INRA and ANR - the French National Research Agency program "Agriculture et Développement Durable" grant "ANR-05-PADD-05, CEDRE". 


\section{References}

Agrios, 2005 G. Agrios Plant Pathology (5th edition), Elsevier-Academic Press, San Diego, USA (2005)

Alexander, 2010 H.M. Alexander Disease in natural plant populations, communities and ecosystems: insights into ecological and evolutionary processes Plant Dis., 94 (2010), pp. 492-503

Ambec et al., 2008 S. Ambec, C. Langinier, S. Lemarié Incentive to reduce crop trait durability Am. J. Agric. Econ., 90 (2008), pp. 379-391

Antonovics et al., 2011 J. Antonovics, P.H. Thrall, J.J. Burdon, A.L. Laine Partial resistance in the LinumMelampsora host-pathogen system: does partial resistance make the red queen run slower? Evolution, 65 (2011), pp. 512-522

Barrett et al., 2009 L.G. Barrett, P.H. Thrall, P.N. Dodds, M.M. Van der Merwe, C.C. Linde, G.J. Lawrence, J.J. Burdon Diversity and evolution of effector loci in natural populations of the plant pathogen Melampsora lini Mol. Biol. Evol., 26 (2009), pp. 2499-2513

Bergez et al., 2010 J.E. Bergez, N. Colbach, O. Crespo, F. Garcia, M.H. Jeuffroy, E. Justes, C. Loyce, N. MunierJolain, W. Sadok Designing crop management systems by simulation Eur. J. Agron., 32 (2010), pp. 3-9

Bocci and Chable, 2008 R. Bocci, V. Chable Semences paysannes en Europe: enjeux et perspectives

Cahiers d'études et de recherche francophones/Agricultures, vol. 17 (2008) pp. 216-221

Bonneuil and Thomas, 2009 C. Bonneuil, F. Thomas Gènes, Pouvoirs et Profits. Recherche Publique et Régimes de Production des Savoirs de Mendel aux OGM Quae, Paris, France (2009)

Bousset, 2011 L. Bousset Point de vue sur l'articulation de concepts disciplinaires: application à la gestion de la maîtrise des épidémies sur les cultures dans les agro-écosystèmes INRA, Document de travail (2011) 76 pp.

Bousset et al., 2011 L. Bousset, H. Brun, A.M. Chèvre, R. Delourme Quel lien entre l'épidémiologie, la création variétale et le potentiel de durabilité des résistances? Illustration chez le phoma du colza Innov. Agron., 15 (2011), pp. 31-45

Bousset and Chèvre, 2012 L. Bousset, A.M. Chèvre Controlling cyclic epidemics on the crops of the agroecosystems: articulate all the dimensions in the formalisation, but look for a local solution J. Bot. (2012) (ID 938218) doi:10.1155/2012/938218.

Breukers et al., 2007 M.L.H. Breukers, W. van der Werf, J.P.C. Kleijnen, M.C.M. Mourits, A.O. Lansink Costeffective control of a quarantine disease: a quantitative exploration using design of experiments methodology and bio-economic modelling Phytopathology, 97 (2007), pp. 945-957

Brown and Hovmøller, 2002 J.K.M. Brown, M.S. Hovmøller Aerial dispersal of pathogens on the global and continental scales and its impact on plant disease Science, 297 (2002), pp. 537-541

Browning and Frey, 1969 J.A. Browning, K.J. Frey Multiline cultivars as means of disease control Annu. Rev. Phytopathol., 7 (1969), pp. 355-382

Brun et al., 2010 H. Brun, A.M. Chèvre, B.D.L. Fitt, S. Powers, A.L. Besnard, M. Ermel, V. Huteau, B. Marquer, F. Eber, M. Renard, D. Andrivon Quantitative resistance increases the durability of qualitative resistance to Leptosphaeria maculans in Brassica napus New Phytol., 185 (2010), pp. 285-299

Brush and Perales, 2007 S.B. Brush, H. Perales A maize landscape: ethnicity and agro-biodiversity in Chiapas, Mexico Agric. Ecosyst. Environ., 121 (2007), pp. 211-221

Burdon and Thrall, 2008 J.J. Burdon, P.H. Thrall Pathogen evolution across the agro-ecological interface: implications for management Evol. Appl., 1 (2008), pp. 57-65

Burdon and Thrall, 2009 J.J. Burdon, P.H. Thrall Coevolution of plants and their pathogens in natural habitats Science, 324 (2009), pp. 755-756

Burel and Baudry, 2005 F. Burel, J. Baudry Habitat quality and connectivity in agricultural landscapes: the role of land use systems at various scales in time Ecol. Indic., 5 (2005), pp. 305-313

Cheatham et al., 2009 M.R. Cheatham, M.N. Rouse, P.D. Esker, S. Ignacio, W. Pradel, R. Raymundo, A.H. Sparks, G.A. Forbes, T.R. Gordon, G.A. Garrett Beyond yield: plant disease in the context of ecosystem services Phytopathology, 99 (2009), pp. 1228-1236

Chevassus-au-Louis, 2006 B. Chevassus-au-Louis Refonder la recherche agronomique: leçons du passé, enjeux du siècle Leçon inaugurale du groupe ESA, Angers (2006) 30 pp.

Costanza et al., 1997 R. Costanza, R. d'Arge, R. de Groot, S. Farberk, M. Grasso, B. Hannon, K. Limburg, S. Naeem, R.V. O'Neill, J. Paruelo, R.G. Raskin, P. Suttonkk, M. van den Belt The value of the world's ecosystem services and natural capital Nature, 387 (1997), pp. 253-260 
Damgaard and Østergård, 1999 C. Damgaard, H. Østergård Coevolution of the gene-for-gene system in a metapopulation model of a plant host and a pathogen without a cost of virulence and resistance J. Theor. Biol., 201 (1999), pp. 1-12

Daverdin et al., 2012 G. Daverdin, T. Rouxel, L. Gout, J.N. Aubertot, I. Fudal, M. Meyer, F. Parlange, J. Carpezat, M.H. Balesdent Genome structure and reproductive behaviour influence the evolutionary potential of a fungal pathogen

Delaunay et al., 2008 S. Delaunay, R.P. Tescar, A. Oualbégo, K. Vom Brocke, J. Lançon La culture du coton ne bouleverse pas les échanges traditionnels de semences de sorgho Cahiers Agric., 17 (2008), pp. 189-194

Doré et al., 2011 T. Doré, D. Makowski, E. Malézieux, N. Munier-Jolain, M. Tchamitchian, P. Tittonell Facing up to the paradigm of ecological intensification in agronomy: revisiting methods, concepts and knowledge Eur. J. Agron., 34 (2011), pp. 197-210

Fabre et al., 2012 F. Fabre, E. Rousseau, L. Mailleret, B. Moury Durable strategies to deploy plant resistance in agricultural landscapes New Phytol., 193 (2012), pp. 1064-1075

Finckh and Wolfe, 2006 M.R. Finckh, M.S. Wolfe Diversification strategies B.M. Cooke, D.G. Jones, B. Kaye (Eds.), The Epidemiology of Plant Diseases (2nd edition), Springer, Dordrecht, The Netherlands (2006), pp. 269-308

Gandon et al., 1996 S. Gandon, Y. Capowiez, Y. Dubois, Y. Michalakis, I. Olivieri Local adaptation and gene-forgene coevolution in a metapopulation model Proc. R. Soc. London B, 263 (1996), pp. 1003-1009

Gilbert, 2002 G.S. Gilbert Evolutionary ecology of plant disease in natural ecosystems Ann. Rev. Phytopathol., 40 (2002), pp. 13-43

Gilligan and van den Bosch, 2008 C.A. Gilligan, F. van den Bosch Epidemiological models for invasion and persistence of pathogens Ann. Rev. Phytopathol., 46 (2008), pp. 385-418

Gilpin and Hanski, 1991 M. Gilpin, I. Hanski Metapopulation Dynamics: Empirical and Theoretical Investigations Harcourt Brace Jovanovich, London, UK (1991)

Glaszmann et al., 2010 J.C. Glaszmann, B. Kilian, H.D. Upadhyaya, R.K. Varshney Accessing genetic diversity for crop improvement Curr. Opin. Plant Biol., 13 (2010), pp. 167-173

Goldman et al., 2007 R.L. Goldman, B.H. Thompson, G.C. Daily Institutional incentives for managing the landscape: inducing cooperation for the production of ecosystem services Ecol. Econ., 64 (2007), pp. 333-343 Hanski, 1999 I. Hanski Metapopulation Ecology Oxford University Press, Oxford, UK (1999)

Hanson et al., 2007 J.D. Hanson, M.A. Liebig, S.D. Merrill, D.L. Tanaka, J.M. Krupinsky, D.E. Stott Dynamic cropping systems: increasing adaptability amid an uncertain future Agron. J., 99 (2007), pp. 939-943

Hossard et al., 2010 L. Hossard, C. Lannou, J. Papaïx, H. Monod, E. Lô-Pezler, V. Souchère, M.H. Jeuffroy Quel déploiement spatio-temporel des variétés et des itinéraires techniques pour accroître la durabilité des résistances variétales? Innov. Agron., 8 (2010), pp. 15-33

Hovmøller et al., 1997 M.S. Hovmøller, H. Østergård, L. Munk Modelling virulence dynamics of airborne plant pathogens in relation to selection by host resistance in agricultural crops I.R. Crute, J.J. Burdon, E.B. Holub (Eds.), The Gene-for-Gene Relationship in Host-Parasite Interactions, CAB International, Wallingford, UK (1997), pp. 173-190

Hulme, 2009 P.E. Hulme Trade, transport and trouble: managing invasive species pathways in an era of globalization J. Appl. Ecol., 46 (2009), pp. 10-18

Janzac et al., 2009 B. Janzac, F. Fabre, A. Palloix, B. Moury Constraints on evolution of virus avirulence factors predict the durability of corresponding plant resistances Mol. Plant Pathol., 10 (2009), pp. 599-610

Jarvis et al., 2008 D.I. Jarvis, A.D.H. Brown, P.H. Cuong, L. Collado-Panduro, L. Latourniere-Moreno, S. Gaywali, T. Tanto, M. Sawadogo, I. Mar, M. Sadiki, N.T.N. Hue, L. Arias-Reyes, D. Balma, J. Bajrachary, F. Castillo, D. Rijal, L. Belqadi, R. Rana, S. Saidi, J. Ouedraogo, R. Zangre, K. Rhrib, J.L. Chavez, D. Schoen, B. Sthapit, P. De Santis, C. Fadda, T. Hodgkin A global perspective of the richness and evenness of traditional crop variety diversity maintained by farming communities Proc. Natl. Acad. Sci. U.S.A., 108 (2008), pp. 53265331

Johnson, 1984 R. Johnson A critical analysis of durable resistance Ann. Rev. Phytopathol., 22 (1984), pp. 309-330

Krupinsky et al., 2002 J.M. Krupinsky, K.L. Bailey, M.P. McMullen, B.D. Gossenb, T. Kelly Managing plant disease risk in diversified cropping systems Agron. J., 94 (2002), pp. 198-209 
Laine et al., 2011 A.L. Laine, J.J. Burdon, P.N. Dodds, P.H. Thrall Spatial variation in disease resistance: from molecules to metapopulations J. Ecol., 99 (2011), pp. 96-112

Lansink, 2011 A.O. Lansink Public and private role in plant health management Food Policy, 36 (2011), pp. 166170

Leach et al., 2001 J.E. Leach, C.M. Vera Cruz, J. Bai, H. Leung Pathogen fitness penalty as a predictor of durability of disease resistance genes Ann. Rev. Phytopathol., 39 (2001), pp. 187-224

Leenhardt et al., 2010 D. Leenhardt, F. Angevin, A. Biarnès, N. Colbach, C. Mignolet Describing and locating cropping systems at a regional scale Agron. Sustain. Dev., 30 (2010), pp. 131-138

Leonard, 1993 K.J. Leonard Stability of equilibria in a gene-for-gene coevolution model of host-parasite interactions Phytopathology, 84 (1993), pp. 70-77

Lô-Pelzer et al., 2009 E. Lô-Pelzer, J.N. Aubertot, O. David, M.H. Jeuffroy, L. Bousset Relationship between the severity of phoma stem canker (Leptosphaeria maculans/L. biglobosa species complex) and subsequent primary inoculum production on oilseed rape stubble Plant Pathol., 58 (2009), pp. 61-70

Lô-Pelzer et al., 2010 E. Lô-Pelzer, L. Bousset, M.H. Jeuffroy, M.U. Salam, J.N. Aubertot SIPPOM-WOSR: a simulator for integrated pathogen population management of phoma stem canker on winter oilseed rape. I. Description of the model Field Crops Res., 118 (2010), pp. 73-81

Loucks, 1977 O.L. Loucks Emergence of research on agro-ecosystems Ann. Rev. Ecol. Syst., 8 (1977), pp. 173-192 Margosian et al., 2009 M.L. Margosian, K.A. Garrett, J.M.S. Hutchinson, K.A. With Connectivity of the American agricultural landscape: assessing the national risk of crop pest and disease spread Bioscience, 59 (2009), pp. 141-151

McDonald and Linde, 2002 B.A. McDonald, C. Linde Pathogen population genetics, evolutionary potential, and durable resistance Ann. Rev. Phytopathol., 40 (2002), pp. 349-379

Millenium Ecosystem Assessment, 2005 Millenium Ecosystem Assessment (MEA) Appendix D - glossary Vol. 1. Current State and Trends Assessment, Island Press, Washington, DC, USA (2005)

Morris et al., 2009 C.E. Morris, M. Bardin, L.L. Kinkel, B. Moury, P.C. Nicot, D.C. Sands Expanding the paradigms of plant pathogen life history and evolution of parasitic fitness beyond agricultural boundaries PLoS Pathog., 5 (2009), p. e1000693

Pannell and Charlesworth, 2000 J.R. Pannell, B. Charlesworth Effects of metapopulation processes on measures of genetic diversity Philos. Trans. R. Soc. London B, 29 (2000), pp. 1851-1864

Papaïx et al., 2011 J. Papaï, H. Goyeau, P. Du Cheyron, H. Monod, C. Lannou Influence of cultivated landscape composition on variety resistance: an assessment based on wheat leaf rust epidemics New Phytol., 191 (2011), pp. 1095-1107

Pietravalle et al., 2006 S. Pietravalle, S. Lemarié, F. van den Bosch Durability of resistance and cost of virulence Eur. J. Plant Pathol., 114 (2006), pp. 107-116

Pretty, 2008 J. Pretty Agricultural sustainability: concepts, principles and evidence Philos. Trans. R. Soc. London B, 363 (2008), pp. 447-465

Prospero et al., 2009 S. Prospero, N.J. Grünwald, L.M. Winton, E.M. Hansen Migration patterns of the emerging plant pathogen Phytophthora ramorum on the west coast of the United States of America Phytopathology, 99 (2009), pp. 739-749

REX Consortium, 2007 REX Consortium Structure of the scientific community modelling the evolution of resistance PLoS ONE, 2 (2007), p. e1275

Rouxel et al., 2011 T. Rouxel, J. Grandaubert, J.K. Hane, C. Hoede, A.P. van de Wouw, A. Couloux, V. Dominguez, V. Anthouard, P. Bally, S. Bourras, A.J. Cozijnsen, L.M. Ciuffetti, A. Degrave, A. Dilmaghani, L. Duret, I. Fudal, S.B. Goodwin, L. Gout, N. Glaser, J. Linglin, G.H.J. Kema, N. Lapalu, C.B. Lawrence, K. May, M. Meyer, B. Ollivier, J. Poulain, C.L. Schoch, A. Simon, J.W. Spatafora, A. Stachowiak, B.G. Turgeon, B.M. Tyler, D. Vincent, J. Weissenbach, J. Amselem, H. Quesneville, R.P. Oliver, P. Wincker, M.H. Balesdent, B.J. Howlett Effector diversification within compartments of the Leptosphaeria maculans genome affected by repeat-induced point mutations Nature Commun., 2 (2011), p. 202

Rouxel et al., 2001 T. Rouxel, A. Penaud, X. Pinochet, H. Brun, L. Gout, R. Delourme, J. Schmit, M.H. Balesdent A 10-year survey of populations of Leptosphaeria maculans in France indicates a rapid adaptation towards the Rlm1 resistance gene of oilseed rape Eur. J. Plant Pathol., 109 (2001), pp. 871-881 
Rozenfeld et al., 2008 A.F. Rozenfeld, S. Arnaud-Haond, E. Hernández-García, V.M. Eguíluz, E.A. Serrão, C.M. Duarte Network analysis identifies weak and strong links in a metapopulation system Proc. Natl. Acad. Sci. U.S.A., 105 (2008), pp. 18824-18829

Sadok et al., 2009 W. Sadok, F. Angevin, J.E. Bergez, C. Bockstaller, B. Colomb, L. Guichard, R. Reau, A. Messéan, T. Doré MASC: a qualitative multi-attribute decision model for ex ante assessment of the sustainability of cropping systems Agron. Sustain. Dev., 29 (2009), pp. 447-461

Sapoukhina et al., 2009 N. Sapoukhina, C.E. Durel, B. Le Cam Spatial deployment of gene-for-gene resistance governs evolution and spread of pathogen populations Theor. Ecol., 2 (2009), pp. 229-238

Savary et al., 2006 S. Savary, P.S. Teng, L. Willocquet, F.W.J. Nutter Quantification and modelling of crop losses: a review of purposes Annu. Rev. Phytopathol., 44 (2006), pp. 89-112

Schwarzbach, 1998 E. Schwarzbach The mlo based resistance of barley to mildew and the response of mildew populations to the use of varieties with the mlo gene Czech J. Genet. Plant Breed., 34 (1998), pp. 3-10

Smith et al., 2011 D.L. Smith, L. Ericson, J.J. Burdon Co-evolutionary hot and cold spots of selective pressure move in space and time J. Ecol., 99 (2011), pp. 634-641

Sosnowski et al., 2009 M.R. Sosnowski, J.D. Fletcher, A.M. Daly, B.C. Rodoni, S.L.H. Viljanen-Rollinson Techniques for the treatment, removal and disposal of host material during programmes for plant pathogen eradication Plant Pathol., 58 (2009), pp. 621-635

Stoate et al., 2009 C. Stoate, A. Báldi, P. Beja, N.D. Boatman, I. Herzon, A. van Doorn, G.R. de Snoo, L. Rakosy, C. Ramwell Ecological impacts of early 21 st century agricultural change in Europe - a review J. Environ. Manage., 91 (2009), pp. 22-46

Stukenbrock and McDonald, 2008 E.H. Stukenbrock, B.A. McDonald The origins of plant pathogens in agroecosystems Annu. Rev. Phytopathol., 46 (2008), pp. 75-100

Sun and Yang, 1999 P. Sun, X.B. Yang Two properties of a gene-for-gene coevolution system under human perturbations Phytopathology, 89 (1999), pp. 811-816

Thomas et al., 2011 M. Thomas, J.C. Dawson, I. Goldringer, C. Bonneuil Seed exchanges, a key to analyze crop diversity dynamics in farmer-led on-farm conservation Genet. Res. Crop Evol., 58 (2011), pp. 321-338

Thompson, 2005 J.N. Thompson The Geographic Mosaic of Coevolution Chicago University Press, Chicago, USA (2005)

Thrall et al., 2003 P.H. Thrall, R. Godfree, J.J. Burdon Influence of spatial structure on pathogen colonization and extinction: a test using an experimental metapopulation Plant Pathol. (2003), pp. 350-361

Vanloqueren and Baret, 2008 G. Vanloqueren, P.V. Baret Why are ecological, low-input, multi-resistant wheat cultivars slow to develop commercially? A Belgian agricultural 'lock-in' case study Ecol. Econ., 66 (2008), pp. $436-446$

Vera Cruz et al., 2000 C.M. Vera Cruz, J.F. Bai, I. Oña, H. Leung, R.J. Nelson, T.W. Mew, J.E. Leach Predicting durability of a disease resistance gene based on an assessment of the fitness loss and epidemiological consequences of avirulence gene mutation Proc. Natl. Acad. Sci. U.S.A., 97 (2000), pp. 13500-13505

Zhu et al., 2000 Y. Zhu, H. Chen, J. Fan, Y. Wang, Y. Li, J. Chen, J. Fan, S. Yang, L. Hu, H. Leung, T.W. Mew, P.S. Teng, Z. Wang, C.C. Mundt Genetic diversity and disease control in rice Nature, 406 (2000), pp. 718722 